\title{
Picroside II Could Reduce the Concentration of NO and Enhance the Activity of GSHPx in Cerebral Ischemic Injury in Rats
}

\author{
Yue Wang ${ }^{1}$, Rui Zhang ${ }^{2}$, Liang Zhong ${ }^{2}$, Guangyi Liu ${ }^{2}$ and Xiao-Jun $\mathrm{Ji}^{2}$ \\ ${ }^{1}$ Department of Neurology, Qingdao Municipal Hospital, Qingdao, China \\ ${ }^{2}$ Department of Neurology, Affiliated Hospital of Qingdao University, Qingdao, China
}

Correspondence should be addressed to: Yue Wang; wangyuehh@126.com

Received Date: 8 August 2013; Accepted Date: 2 December 2013; Published Date: 21 January 2014

Academic Editor: Keiichi Shimamura

Copyright @ 2014 Yue Wang, Rui Zhang, Liang Zhong, Guangyi Liu and Xiao-Jun Ji. Distributed under Creative Commons CC-BY 3.0

\begin{abstract}
Picroside II could reduce the oxidative damage induced by cerebral ischemia-reperfusion and improve nerve behavior function of rats. The aim of this study was to optimize the therapeutic dose and time window of picrosede II by orthogonal test in cerebral ischemic injury in rats. The forebrain ischemia models were established by bilateral common carotid artery occlusion (BCCAO) methods. The successful models were randomly grouped according to orthogonal experimental design and treated by injecting picroside II intraperitonenally at different ischemic time with different dose. The concentration nitric oxide (NO) in serum and brain tissue were determined by nitratase reductase assay. The activity of glutathione peroxidase (GSHPx) in serum and tissue were determined by chemical colormetry. The optimized composition of the therapeutic dose and time window of picroside II in cerebral ischemic injury was (1) ischemia $1.5 \mathrm{~h}$ with $20 \mathrm{mg} / \mathrm{kg}$ body weight according to the concentrations of NO in serum and brain tissue; (2) ischemia $1.5 \mathrm{~h}$ with $10 \mathrm{mg} / \mathrm{kg}$ and ischemia $2.0 \mathrm{~h}$ with $20 \mathrm{mg} / \mathrm{kg}$ body weight according to the activities of GSHPx in serum and brain tissue. From the principle of lowest therapeutic dose with longest time window, the optimized composition of the therapeutic dose and time window of picroside II in cerebral ischemic injury is ischemia 1.5$2.0 \mathrm{~h}$ with $10-20 \mathrm{mg} / \mathrm{kg}$ body weight.
\end{abstract}

Keywords: Picroside II, Cerebral ischemia, NO, GSHPx.

\section{Introduction}

As a free radical, nitric oxide (NO) reacts with $\mathrm{O2}$ - to produce $\mathrm{OH}-$ and $\mathrm{NO2-}$, which are more toxic than $\mathrm{NO}$ and contribute to disturbing the function of the respiratory chain, induction of DNA damage and cell apoptosis and aggravation of ischemia- reperfusion injury (Ito et al.,2010). Under physiological condition, there is no expression of inducible nitric oxide synthase (iNOS). The release of local excitatory amino acid (EAA) was increased after cerebral ischemia-reperfusion, which activates iNOS and induces NO synthesis (Choi et al., 2010; Wang et al., 2011). This

Cite this Article as: Yue Wang, Rui Zhang, Liang Zhong, Guangyi Liu and Xiao-Jun Ji (2014), "Picroside II Could Reduce the Concentration of NO and Enhance the Activity of GSHPx in Cerebral Ischemic Injury in Rats," Research in Neurology: An International Journal, Vol. 2014 (2014), Article ID 488911, DOI: $10.5171 / 2014.488911$ 
effect is associated with lipid peroxide (Caso et al., 2008; Bi et al., 2009) and induction of cell apoptosis or death (Brown et al., 2010, Perluigi et al., 2010; Rey et al., 2011). After cerebral ischemia, increased production of free radical promoted degeneration and necrosis of vascular endothelial cell, aggravated infarction edema and destroyed reconstruction of blood supply in infarct area (Bailey et al., 2004). Under normal circumstances, the presence of effective antioxidant system is required to maintain the physiological levels of free radicals. Glutathione peroxidase (GSHPx) can convert $\mathrm{H} 2 \mathrm{O} 2$ into $\mathrm{H} 2 \mathrm{O}$ and eliminate the toxic action of oxygen free radical (Yan et al., 2008; Wang et al., 2010). Cell culture assay shows that picroside II can reduce damage of $\mathrm{H} 2 \mathrm{O} 2$ induced PC12 cells and improve cell survival rate (Li et al., 2002, Tao et al., 2003; Guo et al., 2007). Picroside II, which is an iridoid glucoside, is an active constituent extracted from the traditional Chinese medicine (TCM) hu-huang-lian, Animal experiments indicate that picroside II might regulate the expressions of iNOS, SOD and Caspase-9 (Li et al., 2010; Sun et al., 2011) to inhibit the neuronal apoptosis induced by cerebral ischemia reperfusion injury and improve the neurological function of animals (Li et al., 2010; Li et al., 2010). Author's former research indicated that the optimized therapeutic dose and time window is injecting picroside II intraperitonenally with $10-20 \mathrm{mg} / \mathrm{kg}$ body weight at ischemia $1.5 \mathrm{~h}$ in cerebral ischemic injury in rats (Pei et al., 2012). The authors aimed to further explore the optimum therapeutic dose and time window according to the quantitative measurement of NO and GSHPx level in blood and brain homogenates.

\section{Materials and Methods}

\section{Animal Models}

A total of $\underline{78}$ adult healthy male Wistar rats, SPF grade, weight 230-250 g, were supplied by the Experiment Animal Center of Qingdao Drug Inspection Institute (SCXK (LU) 20100010). All animals were given time to adapt to the laboratory environment, allowed free access to food and water in a housing with natural illumination for a week. The room temperature was controlled at $23 \pm 2{ }^{\circ} \mathrm{C}$. All rats were randomly divided into shamoperation group with $\underline{10}$ rats, model group with 10 rats and treatment group with 48 rats. All animals were fasted $12 \mathrm{~h}$ before operation. The rats were anesthetized by injecting intraperitoneally $10 \%$ chloral hydrate $(300 \mathrm{ml} / \mathrm{kg})$ and fixed in supine position to conduct aseptic operation. Global forebrain ischemia models were established by bilateral common carotid artery occlusion (BCCAO) of rats (MárquezMartín et al., 2012). The successful rat models of global forebrain ischemia were internalized into the experiment group (ten rats that unconsciousness or dead 2 hours after operation were excluded). The rats in the sham operation group underwent the same surgical procedures except BCCAO operation. The Local Ethical Committee of Experimental Animals of Medical College of Qingdao University approved that all the steps of this study were compliant with ethical rules.

\section{Orthogonal Experimental Design}

Total 48 successful global forebrain ischemia rat models of treatment group were internalized into the experiment and divided randomly according to the principle of orthogonal experimental design of [L16(45)] consisting of two impact factors with four impact levels (Table 1). The impact factor $A$ is the therapeutic time widow designed four levels: $1.0 \mathrm{~h}, 1.5 \mathrm{~h}, 2.0 \mathrm{~h}, 2.5 \mathrm{~h}$ after ischemia. The impact factor $B$ is the therapeutic drug dose which has four levels as follows: $5 \mathrm{mg} / \mathrm{kg}, 10 \mathrm{mg} / \mathrm{kg}, 20 \mathrm{mg} / \mathrm{kg}$ and $40 \mathrm{mg} / \mathrm{kg}$ body weight. The orthogonal experiment was repeated 3 times. 
Table 1: Orthogonal Experimental Design of [L16 (45)]

\begin{tabular}{|l|l|l|l|l|}
\hline $\begin{array}{l}\text { Therapeutic } \\
\text { dose }\end{array}$ & $\begin{array}{l}\text { Ischemia } \\
\mathbf{1 . 0 h}(\mathbf{A 1})\end{array}$ & $\begin{array}{l}\text { Ischemia } \\
\mathbf{1 . 5 h}(\mathbf{A 2})\end{array}$ & $\begin{array}{l}\text { Ischemia } \\
\mathbf{2 . 0 h}(\mathbf{A 3})\end{array}$ & $\begin{array}{l}\text { Ischemia } \\
\mathbf{2 . 5 h}(\mathbf{A 4})\end{array}$ \\
\hline $5 \mathrm{mg} / \mathrm{kg}(\mathrm{B} 1)$ & $1.0 \times 5$ & $1.5 \times 5$ & $2.0 \times 5$ & $2.5 \times 5$ \\
\hline $10 \mathrm{mg} / \mathrm{kg}(\mathrm{B} 2)$ & $1.0 \times 10$ & $1.5 \times 10$ & $2.0 \times 10$ & $2.5 \times 10$ \\
\hline $20 \mathrm{mg} / \mathrm{kg}(\mathrm{B} 3)$ & $1.0 \times 20$ & $1.5 \times 20$ & $2.0 \times 20$ & $2.5 \times 20$ \\
\hline $40 \mathrm{mg} / \mathrm{kg}(\mathrm{B} 4)$ & $1.0 \times 40$ & $1.5 \times 40$ & $2.0 \times 40$ & $2.5 \times 40$ \\
\hline
\end{tabular}

\section{Treatment Methods}

Picroside II (Tianjin Kuiqing Medical Technology Co., Ltd., CAS No: 39012-20-9, purity $>98 \%$, Molecular formula: C23H28013, Molecular weight: 512.48) was diluted into $1 \%$ solution with saline solution and injected intraperitoneally according to the corresponding designed doses and ischemia time (Pei et al., 2012) in the orthogonal layout [L16(45)]. Rats in sham group were simultaneously suffered the same doses saline solution.

\section{Sample Collection}

After treatment with picroside II for $24 \mathrm{~h}$, total of rats were anesthetized with $10 \%$ chloral hydrate $(300 \mathrm{ml} / \mathrm{kg})$ and collected $4 \mathrm{ml}$ blood through heart to centrifuge at $4000 \mathrm{rpm}$ for $10 \mathrm{~min}$ to separate serum. and stored at $-20 \square$. And then the rats were perfused with $200 \mathrm{ml}$ saline solution through heart. The brain was taken out completely through fast craniotomy and the olfactory bulb and prefrontal brain tissue were excised. Five hundreds milligram brain tissue were prepared backward from optic chiasma (Bregma $0.00 \mathrm{~mm}$ ), grinded to power in pre-cooling mortar and then homogenized by ultrasonic wave to extract cellular proteins with lysis buffer (500ul lysis buffer $+5 \mathrm{ul}$ PMSF, No.P0013, Beyotime Institute of Biotechnology. Shanghai, China) according to the proportion of 1:3, centrifuged with refrigerated centrifuge (Model Eppendorf 5801 , Germany) at 12,000 r/min for $10 \mathrm{~min}$ at $4^{\circ} \mathrm{C}$. The supernatant liquid was collected and stored at $-20^{\circ} \mathrm{C}$. The protein concentration in the supernatant was determined by the BCA method (Wuhan Boster Biological Engineering Co., Ltd., China).

\section{Detection Index}

The NO levels and GSHPx activities of serum and brain homogenate were measured by method of nitrate reductase and chemical colorimetry. According to the kit (Nanjing Jiancheng biology technology company) instructions, the serum or brain tissue homogenate were resolved at room temperature and centrifuged. The $100 \mu \mathrm{l}$ supernatant liquid was collected. We measured absorbance value with UV spectrophotometer (Beckmann DU640, USA) at a wavelength of $550 \mathrm{~nm}$ (NO) and $412 \mathrm{~nm}$ (GSHPx) and then calculated the content of NO $(\mu \mathrm{mol} / \mathrm{L})$ content and the activity of GSHPx (U/ml).

\section{Statistical Analysis}

SPSS 17.0 software was used for data statistical analysis. According to the result, multi-group comparison was made by analysis of orthogonal test whether different level of administrating time dose and the therapeutic time window.

\section{Results}

\section{Measurement Results}

In model group, the contents of NO in serum and brain tissue homogenate were increased significantly than those in shamoperated group and the activities of GSHPx were obviously decreased than those in sham-operated group $\quad(t=12.32 \sim 43.86$, $\mathrm{P}<0.01)$. In treatment group, the contents of NO in serum and brain tissue homogenate were obviously decreased than those in model group and the activities of GSHPx were increased significantly than those in model group ( $\mathrm{t}=3.88 \sim 7.64, \mathrm{P}<0.01$. See tables 2 and 3 . 
Table 2: The Measurement Results Results of NO and GSHPx

\begin{tabular}{|l|l|l|l|l|l|}
\hline groups & $\mathbf{n}$ & $\begin{array}{l}\text { Serum No } \\
(\boldsymbol{\mu m o l} / \mathbf{L})\end{array}$ & $\begin{array}{l}\text { Brain NO } \\
(\boldsymbol{\mu m o l} / \mathbf{L})\end{array}$ & $\begin{array}{l}\text { Serum GSHPx } \\
(\mathbf{U} / \mathbf{L})\end{array}$ & $\begin{array}{l}\text { Brain GSHPx } \\
(\mathbf{U} / \mathbf{L})\end{array}$ \\
\hline Sham group & 5 & $45.56 \pm 6.72$ & $1.12 \pm 0.25$ & $328.15 \pm 9.85$ & $635.65 \pm 25.16$ \\
\hline Model group & 5 & $80.33 \pm 9.26 \mathrm{a}$ & $2.67 \pm 0.34 \mathrm{a}$ & $267.14 \pm 8.32 \mathrm{a}$ & $426.17 \pm 20.65 \mathrm{a}$ \\
\hline $\begin{array}{l}\text { Treatment } \\
\text { group }\end{array}$ & 48 & $65.95 \pm 8.90 \mathrm{~b}$ & $1.74 \pm 0.65 \mathrm{~b}$ & $305.81 \pm 25.05 \mathrm{~b}$ & $552.90 \pm 92.17 \mathrm{~b}$ \\
\hline
\end{tabular}

a Compare with sham-operated group, $\mathrm{t}=12.32 \sim 43.86, \mathrm{P}<0.01$; $\mathrm{b}$ compare with model group, $\mathrm{t}=3.88 \sim 7.64, \mathrm{P}<0.01$

Table 3: L16 (45) Orthogonal Layout and the Results of Measurement

\begin{tabular}{|c|c|c|c|c|c|c|c|c|c|}
\hline \multirow{2}{*}{$\begin{array}{l}\text { Test } \\
\text { No. }\end{array}$} & \multicolumn{5}{|c|}{ Rank No. } & \multirow{2}{*}{$\begin{array}{l}\text { Serum } \\
\text { NO }\end{array}$} & \multirow{2}{*}{$\begin{array}{l}\text { Brain } \\
\text { NO }\end{array}$} & \multirow{2}{*}{$\begin{array}{l}\text { Serum } \\
\text { GSHPx }\end{array}$} & \multirow{2}{*}{$\begin{array}{l}\text { Brain } \\
\text { GSHPx }\end{array}$} \\
\hline & A & B & $\mathrm{C}$ & D & $\mathbf{E}$ & & & & \\
\hline 1 & 1 & 1 & 1 & 1 & 1 & 67.50 & 15.06 & 293.67 & 497.11 \\
\hline 2 & 1 & 2 & 2 & 2 & 2 & 66.67 & 14.80 & 303.26 & 513.20 \\
\hline 3 & 1 & 3 & 3 & 3 & 3 & 62.22 & 14.61 & 310.61 & 505.64 \\
\hline 4 & 1 & 4 & 4 & 4 & 4 & 71.11 & 15.08 & 293.99 & 508.64 \\
\hline 5 & 2 & 1 & 2 & 3 & 4 & 71.67 & 14.29 & 291.84 & 519.46 \\
\hline 6 & 2 & 2 & 1 & 4 & 3 & 62.11 & 13.61 & 345.92 & 639.57 \\
\hline 7 & 2 & 3 & 4 & 1 & 2 & 51.39 & 12.14 & 361.64 & 723.05 \\
\hline 8 & 2 & 4 & 3 & 2 & 1 & 56.94 & 14.23 & 313.47 & 633.36 \\
\hline 9 & 3 & 1 & 3 & 4 & 2 & 66.67 & 17.31 & 304.29 & 603.71 \\
\hline 10 & 3 & 2 & 4 & 3 & 1 & 50.56 & 13.70 & 325.71 & 612.87 \\
\hline 11 & 3 & 3 & 1 & 2 & 4 & 54.17 & 14.04 & 322.92 & 689.53 \\
\hline 12 & 3 & 4 & 2 & 1 & 3 & 71.33 & 16.38 & 307.40 & 612.68 \\
\hline 13 & 4 & 1 & 4 & 2 & 3 & 78.22 & 16.71 & 273.55 & 459.08 \\
\hline 14 & 4 & 2 & 3 & 1 & 4 & 72.62 & 16.04 & 301.76 & 437.65 \\
\hline 15 & 4 & 3 & 2 & 4 & 1 & 76.25 & 16.56 & 272.65 & 466.37 \\
\hline 16 & 4 & 4 & 1 & 3 & 2 & 75.83 & 18.17 & 270.20 & 424.40 \\
\hline I & 267.50 & 284.06 & 259.61 & 262.84 & 251.25 & 1055.26 & 242.73 & 4892.88 & 8846.32 \\
\hline II & 242.11 & 251.96 & 285.92 & 256.00 & 260.56 & & & & \\
\hline III & 242.73 & 244.03 & 258.45 & 260.28 & 273.88 & & & & \\
\hline IV & 302.92 & 275.21 & 251.28 & 276.14 & 269.57 & & & & \\
\hline SS & 614.62 & 267.92 & 173.06 & 66.34 & 69.98 & & & & \\
\hline
\end{tabular}

\section{ANOVA Analysis of NO Content}

There was significant difference $(\mathrm{P}<0.01)$ of the content of NO in serum among various ischemia time (factor $A$ ) but no significant difference $(\mathrm{P}>0.05)$ found among various therapeutic dose (factor B) and various interaction between medication time and therapeutic dose (factor C). Pairwise comparisons among data of all independent groups by least- significant-difference (LSD) method showed that there was significant difference $(\mathrm{P}<0.05)$ of NO content in serum between medication time (ischemia time) 1.0h (A1) and $2.5 \mathrm{~h}$ (A4), $1.5 \mathrm{~h}$ (A2) and 2.5 h (A4), 2 h (A3) and 2.5 h (A4), but no significant difference existed between each other for the rest groups $(\mathrm{P}>0.05)$. There was significant difference of NO content between therapeutic dose $5 \mathrm{mg} / \mathrm{kg}$ (B1) and $20 \mathrm{mg} / \mathrm{kg}(\mathrm{B} 3)(\mathrm{P}<0.05)$, but no significant 
difference existed between each other for the rest groups $(\mathrm{P}>0.05)$. Therefore, according to the principle of lowest therapeutic dose with longest time window, A2B3 is the best combination group, i.e., the optimized time window and therapeutic dose is ischemia $1.5 \mathrm{~h}$ with $20 \mathrm{mg} / \mathrm{kg}$ body weight.

There was no significant difference $(P>$ 0.05 ) of NO content in brain tissue among various medication time (factor $A$ ), various therapeutic dose (factor B) and various interaction between medication time and therapeutic dose (factor C). Pairwise comparisons among data of all independent groups by least-significantdifference (LSD) method showed that there was significant difference $(P<0.05)$ of NO content between medication time 1.0h (A1) and $1.5 \mathrm{~h}$ (A2), $1.5 \mathrm{~h}$ (A2) and $2.5 \mathrm{~h}$ (A4), while there was no significant difference between each other for the rest groups $((P$ $>0.05)$. There was no significant difference $(P>0.05)$ among various therapeutic dose. Therefore, according to the principle of lowest therapeutic dose with longest time window, A2B3 is the best combination group, i.e., the optimized time window and therapeutic dose is ischemia $1.5 \mathrm{~h}$ with $20 \mathrm{mg} / \mathrm{kg}$ body weight.

Table 4: ANOVA Analysis of NO Content

\begin{tabular}{|l|l|l|l|l|l|l|l|l|l|l|}
\hline $\begin{array}{l}\text { Variation } \\
\text { source }\end{array}$ & $\begin{array}{l}\text { SS } \\
\text { Serum }\end{array}$ & $\mathbf{d f}$ & MS & F & P & SS Brain & df & MS & F & P \\
\hline Ischemia time & 614.62 & 3 & 204.87 & 9.29 & 0.01 & 2.50 & 3 & 0.83 & 4.54 & 0.06 \\
\hline $\begin{array}{l}\text { Therapeutic } \\
\text { dose }\end{array}$ & 267.92 & 3 & 89.31 & 4.05 & 0.07 & 1.25 & 3 & 0.42 & 2.28 & 0.18 \\
\hline TimexDose & 173.06 & 3 & 57.69 & 2.62 & 0.15 & 1.54 & 3 & 0.51 & 2.79 & 0.13 \\
\hline Error & 132.33 & 6 & 22.06 & & & 1.10 & 6 & 0.18 & & \\
\hline
\end{tabular}

\section{ANOVA Analysis of GSHPx Activity}

There was significant difference $(\mathrm{P}<0.05)$ of the activity of GSHPx in serum among various ischemia time (factor $A$ ) and various therapeutic dose (factor B), but the interaction between medication time and therapeutic dose (factor $\mathrm{C}$ ) was negligible $(\mathrm{P}>0.05)$. Pairwise comparisons among data of all independent groups by leastsignificant-difference (LSD) method showed that there was no significant difference $(\mathrm{P}>0.05)$ of the activity of GSHPx in serum between medication time (ischemia time) 1.0h (A1) and $2 \mathrm{~h}$ (A3), 1.5 h (A2) and 2 h (A3), but significant difference existed between each other for the rest groups $(\mathrm{P}<0.05)$. There was no significant difference of the activity of GSHPx in serum between therapeutic dose $5 \mathrm{mg} / \mathrm{kg}$ (B1) and 40mg/kg (B4), 10mg/kg (B2) and $20 \mathrm{mg} / \mathrm{kg}$ (B3) (P > 0.05), but a significant difference existed between each other for the rest groups $(\mathrm{P}<0.05)$. Therefore, according to the principle of lowest therapeutic dose with longest time window, A2B2 is the best combination group, i.e., the optimized time window and therapeutic dose is ischemia $1.5 \mathrm{~h}$ with $10 \mathrm{mg} / \mathrm{kg}$ body weight.

There was significant difference $(\mathrm{P}<0.05)$ of the activity of GSHPx in brain tissue among various ischemia time (factor $A$ ), but the therapeutic dose (factor B) and the interaction between medication time and therapeutic dose (factor $\mathrm{C}$ ) were negligible $(\mathrm{P}>0.05)$. Pairwise comparisons among data of all independent groups by leastsignificant-difference (LSD) method showed that no significant difference ( $\mathrm{P}>$ 0.05 ) of the activity of GSHPx in brain tissue between medication time 1.0h (A1) and $2.5 \mathrm{~h}$ (A3), $1.5 \mathrm{~h}$ (A2) and $2.0 \mathrm{~h}$ (A3), while there was significant difference between each other for the rest groups $(\mathrm{P}<$ $0.05)$. There was significant difference of the activity of GSHPx in brain tissue between therapeutic dose $5 \mathrm{mg} / \mathrm{kg}$ (B1) and $20 \mathrm{mg} / \mathrm{kg}$ (B3) $(\mathrm{P}<0.05)$, but no significant difference existed between each other for the rest groups $(\mathrm{P}>0.05)$. Therefore, according to the principle of lowest therapeutic dose with longest time window, A3B3 is the best combination group, i.e., the optimized time window and 
therapeutic dose is ischemia $2.0 \mathrm{~h}$ with $20 \mathrm{mg} / \mathrm{kg}$ body weight.

Table 5: ANOVA Analysis of GSHPx Activity

\begin{tabular}{|l|l|l|l|l|l|l|l|l|l|l|}
\hline $\begin{array}{l}\text { Variation } \\
\text { source }\end{array}$ & $\begin{array}{l}\text { SS } \\
\text { Serum }\end{array}$ & df & MS & F & P & SS Brain & df & MS & F & P \\
\hline $\begin{array}{l}\text { Ischemia } \\
\text { time }\end{array}$ & 5230.40 & 3 & 1743.47 & 12.30 & 0.01 & 100379.50 & 3 & 33459.83 & 20.72 & 0.01 \\
\hline $\begin{array}{l}\text { Therapeuti } \\
\text { c dose }\end{array}$ & 2471.13 & 3 & 823.71 & 5.81 & 0.03 & 12134.89 & 3 & 4044.96 & 2.51 & 0.16 \\
\hline TimexDose & 862.88 & 3 & 287.63 & 2.03 & 0.21 & 5236.77 & 3 & 1745.59 & 1.08 & 0.43 \\
\hline Error & 850.23 & 6 & 141.71 & & & 9688.57 & 6 & 1614.76 & & \\
\hline
\end{tabular}

\section{Discussion}

Modern medical studies show that the active ingredients of traditional Chinese medicine have good neuroprotective effect. Salvia miltiorrhiza (Zhang et al., 2010) and calycosin (Guo et al., 2012) could reduce mitochondrial injury induced by cerebral ischemia-reperfusion in rats, significantly decrease contents of MDA (Malondialdehyde) and protein hydroxyl compounds, upregulate the activity of SOD (Superoxide dismutase), CAT (Catalase) and GSHPx, and at the same time, inhibit the expression of 4-Hydroxy-2-nonenal. Chrysophanol formulations ( $\mathrm{Li}$ and Zhang et al., 2010) could significantly increase the activities of GSHPx in whole blood and SOD in plasma in rats with cerebral ischemia reperfusion, and improve the prognosis in ischemic cerebrovascular disease. Liquiritin (Sun et al., 2010) could decrease the content of MDA in brain tissue of mice and increase the activities of CAT and GSHPx. Salidroside (Yan et al., 2008) can obviously reduce the content of NO in rats with cerebral ischemia reperfusion, and improve the damage of neurons induced by ischemia reperfusion, the mechanism of which may be the enhanced expression of downstream step in pathways of intracellular mitogen-activated protein kinase (Li et al., 2002; Li et al., 2000). Cell culture assay shows that picroside II has obvious protective effect on damage of $\mathrm{H}_{2} \mathrm{O}_{2}$-induced PC12 cells, which has a relationship with effect of direct scavenging oxygen free radicals and enhancing cell itself function of antioxidant system (Tao et al., 2003). Experiments on animal models indicate that picroside II could improve the antioxidant capacity of brain tissue in cerebral ischemic injury in rats, reduce the oxidative damage induced by cerebral ischemia-reperfusion and improve nerve behavior function of rats (Zhao et al., 2010).

As the detection index of this experiment, NO can directly reflect changes of free radical content in cerebral ischemic injury and GSHPx can reflect the change of antioxidant content in cerebral ischemic injury. In this experiment, the authors designed four time points at $1 \mathrm{~h}, 1.5 \mathrm{~h}, 2 \mathrm{~h}$ and $2.5 \mathrm{~h}$ after brain ischemic injury in rats, and inject intraperitoneally picroside II with four therapeutic doses of $5 \mathrm{mg} / \mathrm{kg}, 10$ $\mathrm{mg} / \mathrm{kg}, 20 \mathrm{mg} / \mathrm{kg}$ and $40 \mathrm{mg} / \mathrm{kg}$. The experiment was carried out according to orthogonal table of $\left[\mathrm{L} 16\left(4^{5}\right)\right]$ to explore the best therapeutic dose and best time window of picroside II in treating cerebral ischemic injury by determining the expressions of NO and GSHPx. The results indicate that there is significant difference in therapeutic effect among various medication times and various therapeutic doses of picroside II. But the results are not consistent with the best combination of different indexes.

\section{Conclusion}

According to the principle of lowest therapeutic dose with longest time window, the optimized therapeutic dose and time window should be injecting picroside II intraperitonenally with 10$20 \mathrm{mg} / \mathrm{kg}$ body weight at ischemia $1.5-2.0 \mathrm{~h}$.

\section{Acknowledgments}

This work is supported by National Natural Science Foundation of China (Grant No. 81041092) and Natural Science 
Foundation of Shandong Province (Grant No. ZR2011HM050).

\section{References}

Bailey, D. M., Kleger, G. R., Holzgraefe, M., Ballmer. P. E. \& Bärtsch, P. (2004). "Pathophysiological Significance of Peroxidative Stress, Neuronal Damage and Membrane Permeability in Acute Mountain Sickness," Journal of Applide Physiology, 96(4)1459-1463.

Bi, X., Yan, B., Fang, S., et al. (2009). "Quetiapine Regulates Neurogenesis in Ischemic Mice by Inhibiting NF-kB p65/p50 Expression," Neurological Research, 31(2)159-166.

Brown, G. C. (2010). "Nitric Oxide and Neuronal Death," Nitric Oxide, 23(3)153165.

Caso, J. R., Pradillo, J. M., Hurtado, O., Leza, J. C., Moro, M. A. \& Lizasoain, I. (2008). "TollLike Receptor 4 Is Involved in Subacute Stress-Induced Neuroinflammation and in the Worsening of Experimental Stroke," Stroke,39(4) 1314-1320.

Choi, D. W. (1988). "Glutamate Neurotoxicity and Disease of the Nervous System," Neuron, 1(8) 623-634.

Guo, C., Tong, L., Xi, M., Yang, H., Dong, H. \& Wen, A. (2012). "Neuroprotective Effect of Calycosin on Cerebral Ischemia and Reperfusion Injury in Rats," Journal of Ethnopharmacology,144(3)768-774.

Guo, M. C., Cao, Y. \& Liu, J. W. (2007). 'Protective Effects of Picroside II on Glutamate Injury of PC12 Cells,' Chinense Journal of Clinical Pharmacology and Therapeutics,12(4) 440-443.

Ito, Y., Ohkubo, T., Asano, Y., Hattori, K., Shimazu, T.,Yamazato, M., Nagoya, H., Kato, Y. \& Araki, N. (2010). "Nitric Oxide Production during Cerebral Ischemia and Reperfusion in eNOS and nNOS-Knockout Mice," Current Neurovascular Research, 7(1) 23-31.
Li, C., Zhang, D. S., Zhao, X. Q., Shi, F. Y., Zhu, C. L. \& Xue, G. P. (2010). "Experimental Screening Study of Three Chrysophanol Formulations on Learning and Memory Function of Mice with Cerebral Ischemia Reperfusion," Chinese Pharmacological Bulletin, 26(12)1607-1612.

Li, P., Matsunaga, K. \& Ohizumi, Y. (2000). "Nerve Growth Factor Potentiating Compounds from Picrorhizae Rhizome," Biological and Pharmaceutical Bulletin, 23(7)890-892.

Li, P., Matsunaga, K., Yamakuni, T. \& Ohizumi, Y. (2002). "Picrosides I and II, Selective Enhancers of the MitogenActivated Protein Kinase-Dependent Signaling Pathway in the Action of Neuritogenic Substances on PC12D Cells," Life Sciences, 71(15) 1821-1835.

Li, Q., Guo, Y. L., Li, Z. \& Xu, X. Y. (2010). "The Interference of Picroside II on the Expressions of Caspase-3 and PARP Following Cerebral Ischemia Reperfusion Injury in Rats," Chinese Pharmacological Bulletin, 26(3) 342-345.

Li, Q., Li, Z., Xu, X. Y., Guo, Y. L. \& Du, F. (2010). "Neuroprotective Properties of Picroside II in Rat Model of Focal Cerebral Ischemia," International Journal of Molecular Sciences, 11(11) 4580-4590.

Li, Z., Li, Q., Guo, Y. L., Qin, L. H. \& Luan, L. J. (2010). 'Interference Effect of Picroside II on Cerebral Ischemia Reperfusion Injury in Rats,' Acta Anatomica Sinica, 41(1) 9-12.

Márquez-Martín, A., Jiménez-Altayó, F., Dantas, A. P., Caracuel, L., Planas, A. M. \& Vilak, E. (2012). "Middle Cerebral Artery Alterations in a Rat Chronic Hypoperfusion Model," Journal of Applied Physiology, 112(3) 511-518.

Pei, H. T., Su, X., Zhao, L., Li, H. Y., Guo, Y. L., Zhang, M. Z. \& Xin, H. (2012). "Primary Study for the Therapeutic Dose and Time Window of Picroside II in Treating Cerebral Ischemic Injury in Rats," International Journal of Molecular Sciences, 13(2) 25512562. 
Perluigi, M., Di Domenico, F., Giorgi, A., Schininà, M. E., Coccia, R., Cini, C., Bellia, F., Cambria, M. T., Cornelius, C., Butterfield, D. A. \& Calabrese, V. (2010). "Redox Proteomics in Aging Rat Brain: Involvement of Mitochondrial Reduced Glutathione Status and Mitochondrial Protein Oxidation in the Aging Process," Journal of Neuroscience Research, 88(16) 3498-3507.

Rey, B., Roussel, D., Teulier, L., Eyenga, P., Degletagne, C., Belouze, M. \& Duchamp, C. (2011). "Functional Argument for the Existence of an Avian Nitric Oxide Synthase in Muscle Mltochondria:Effect of Cold Acclimation," FEBS Lett, 585(1)173-177.

Sun, L., Li, X. D., Wang, L., Qin, L. H., Guo, Y. L. \& Zhou, Z. (2011). 'The Anti-Oxidant Effect and the Possible Mechanism of Picroside II in Cerebral Ischemia Reperfusion Injury in Rats,' Neural Regeneration Research, 6(15) 1141-1146.

Sun,Y. X., Tang,Y., Wu, A. L., Liu, T., Dai, X. L., Zheng, Q. S. \& Wang, Z. B. (2010). "Neuroprotective Effect of Liquiritin against Focal Cerebral Ischemia/Reperfusion in Mice via Its Antioxidant and Antiapoptosis Properties," Journal of Asian Natural Products Research, 2(12)1051-1060.

Tao, Y. W., Liu, J. W., Wei, D. Z., Su, W. \& Zhou, W. Y. (2003). 'Protective Effect of Picroside- II on the Damage of Cultured PC12 Cells in Vitro,' Chinense Journal of Clinical Pharmacology and Therapeutics, 8(1) 27-30.
Wang, J. Y., Yu, R. \& Yao, M. H. (2010). "Protective Effects and Mechanisms of Salidroside on Cerebral IschemiaReperfusion Injury," China Journal of Traditional Chinese Medicine and Pharmacy, 25 (3) 456-459.

Wang, L.- Q., Jia, J., Guo, M.- F., Zhang, Y., Zhang, X.- Y., Guo, J-. J., Geng, R.- J., Li, B., Zhong, H. \& Li, D.- L. (2011). "Effect of LArginine Amino Guanidine and Agmatine on Focal Cerebral Ischemia-Reperfusion Injury in Rats," Chinese Journal of Pathophysiology, 27(6) 1213-1217.

Yan, T. H., Jia, Y., Yang, W. \& Wang, Q. J. (2008). 'Protective Effects of on Focal Cerebral Ischemic Reperfusion Injury in Rats,' Chinese Pharmacological Bulletin, 24(11) 1521-1524.

Zhang, Q. L., Sun, Y. B., Wang, H. Y., Song, S. J. \& Bai, B. (2010). "Effects of Salvia Miltiorrhiza Bunge. F. Alba. on Mitochondrial Damage and Apoptosis Induced by Cerebral Ischemia and Reperfusion," Athophysiology, 26(4)725729.

Zhao, D. M., Zhang, Z. Q., Duan, Y. X., Zhang, B. Z. \& Liu, Q. S. (2010). 'Neuroprotective Effect of Picroside II on Cerebral IschemiaReperfusion Injury in Rats,' Journal of International Pharmaceutical Research, 37(6)461-468. 